\title{
北川における砂州の地形変化と 植生域変化に関する検討

\author{
RESEARCH ON THE CHANGE OF TOPOGRAPHICAL FEATURES AND \\ VEGETATED REGION ON FLOODPLAIN IN KITA RIVER
}

\author{
杉尾 哲 ${ }^{1} \cdot$ 渡邊訓甫 ${ }^{2}$ \\ Satoru SUGIO $\cdot$ Kunitoshi WATANABE \\ '正会員工博 宮崎大学教授 工学部土木環境工学科（テ889-2192 宮崎市学園木花台西1-1） \\ ${ }^{2}$ 正会員 工博 佐賀大学教授 理工学部都市工学科（广840-8502 佐賀市本庄町1）
}

\begin{abstract}
This paper describes the relation among the flood, topographical features and the vegetated region on the floodplain at Honmura in the Kita River. The past changes in topographical features and the vegetated region were measured from the aerial photographs. The grain sizes of the gravels were investigated at the several points on the floodplain. As a result, the followings have been understood. 1) Gravels piled up due to the flood in 1997, fine sand mixing clay piled up during 1983-1997 and gravels piled up due to the flood in 1982 are accumulated in the vicinity of the $11.7 \mathrm{~km}$ section. 2) Gravels on the bare ground of floodplain moved for the flood of $2,000 \mathrm{~m}^{3} / \mathrm{s}$ in discharge. However, the large scale movement of bed materials did not occur for the flood of $3,500 \mathrm{~m}^{3} / \mathrm{s}$ in discharge if the floodplain was covered by the thick vegetation. 3) The forest zone in the river bend had the effect that the topographical feature of floodplain was stabilized. 4) The state that the herbaceous vegetation covered the whole area of the floodplain, recovered from the state of the bare ground when the condition of $1,600 \mathrm{~m}^{3} / \mathrm{s}$ or less in discharge continued for two and half years. 5) The state with thick vegetation recovered when the condition of $1,800 \mathrm{~m}^{3} / \mathrm{s}$ or less in discharge continued for five years.
\end{abstract}

Key Words : Floodplain, topographical features, vegetated region, grain size of gravel aerial photographs, restoration of vegetation.

\section{1. まえがき}

河川植生は，生態系に重要な役割を果たしているが， 出水時の土砂の流送にも影響するから，その繁茂と破壊 の状態の把握は河川管理上で重要な課題の一つである1). 北川では，1997年9月の台風19号によって激甚な被害が 発生し，河川激甚災害対策特別緊急事業 (以下, 激特事 業という)に採択された。この事業においては, 計画流 量を安全に流下させるために，築堤や流れの障害となる 箇所の樹林の伐採，高水敷の掘削などが実施された2). しかし，その実施規模が大きいため，河川形態や生態系 に及ぼす影響などを把握し，その影響を最小限にとどめ ることが重要であることから, 事業の実施中から, 長期 的な視点でモニタリングが行われている.

これまでのモニタリングによると，物理環境および植 生については, 2001 年 10 月の流量 $1,593 \mathrm{~m}^{3} / \mathrm{s}$ の出水と 2003 年5月の流量 $1,910 \mathrm{~m}^{3} / \mathrm{s}$ の出水によって, 伐採箇所や 高水敷掘削箇所で砂州の地形変化および砂州上の植生破
壊3が観測されている.これらの現象は，比較的小さな 流量規模の出水で発生しているが, これが河川改修後の 初期段階にあるためであるかどうかを評価するには，こ

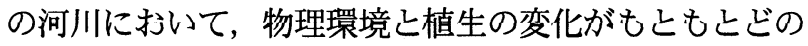
ように繰り返されてきたのかを, 定量的に把握すること が必要となる。

そこで，本論文では，激特事業によって掘削されな かった $12 \mathrm{~km}$ 地点付近の本村砂州を対象として, 砂州の物 理環境と植生の変化を出水規模との関係で評価すること を目的として, 種々の現地調査や資料調査, 聞き取り調 査を行って, 過去の出水に伴う砂州の地形変化と砂州上 の植生域の変化について検討を行った.

\section{2. 研究対象砂州と流況}

北川は，宮崎県の北部を流れる一級水系五ヶ瀬川の一 次支川で, 流域面積 $587 \mathrm{~km}^{2}$, 流路延長 $50.9 \mathrm{~km}$ である. 北 川の激特事業では, 五ヶ瀬川との合流地点から $15.5 \mathrm{~km}$ 地 点までの区間で, 河川環境に配慮した河川改修が実施さ 


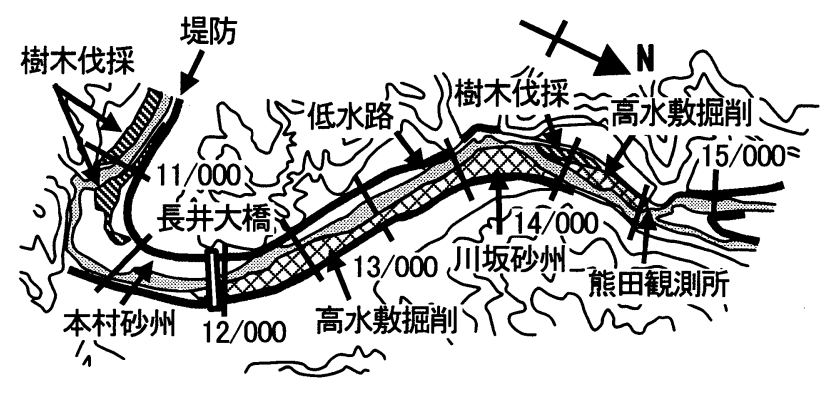

図-1 北川の概略平面図

れた4). 本研究においては, 研究対象砂州として, 激特 事業では掘削対象箇所にならなかった $12 \mathrm{~km}$ 地点付近の本 村地区右岸側に位置する砂州を選定し，特に12.2 $11.6 \mathrm{~km}$ 区間を重点調査の対象区間と選定した.この概略 の位置を図ー 1 に示している.

\section{（1）本村地区の河道特性}

研究対象とした本村地区の河道は，平均的な縦断勾配

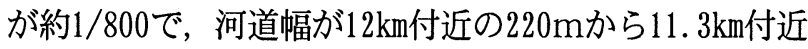
の湾曲部での $430 \mathrm{~m} に$ 徐々に拡大している. 河床材料は, 中央粒径が30〜 40mmの砂礫であり，セグメント分類)で はセグメント2-1に区分されている2).

\section{（2）本村砂州の植生}

12.2〜11. 7km区間の植生は，1997年9月の流量 5,067 $\mathrm{m}^{3} / \mathrm{s}$ の出水で破壊されていたが, その後, 次第に回復し た. 激特事業で掘削された川坂砂州にはアレチハナガサ などの外来植生が進入したが3)，本村砂州においては, もともとこの砂州に生育していた植生が回復した. 2002 年の調査では，区間全面に草本類と木本類が密生する状 況となり，木本類はノイバラ，エノキ，ジャヤナギなど が，草本類はツルコシ，イタドリ，カリラヨ七ギなどけ 群落が分布している6).

\section{（3）流量}

北川の流量は，熊田観測所で観測されている. 1955 2002 年の 48 年間（欠測の 3 年間を含む）の年最大流量を

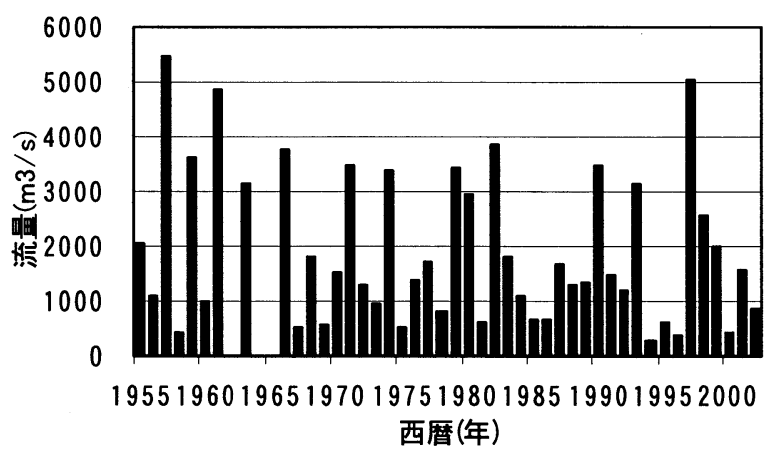

図-2 年最大流量の変化
表- 1 最近の $1,000 \mathrm{~m}^{3} / \mathrm{s}$ 以上の出水

\begin{tabular}{|c|r|c|c|}
\hline 年 & 発生日 & 流量 $\left(\mathrm{m}^{3} / \mathrm{s}\right)$ & 水位 $(\mathrm{m})$ \\
\hline \multirow{3}{*}{1993} & 7月27日 & 1,994 & 5.98 \\
\cline { 2 - 4 } & 7月30日 & 1,305 & 5.00 \\
\cline { 2 - 4 } & 8月10日 & 3,166 & 6.76 \\
\cline { 2 - 4 } & 9月4日 & 3,116 & 6.73 \\
\hline 1997 & 9月16日 & 5,067 & 9.84 \\
\hline 1998 & 5月16日 & 1,033 & 5.06 \\
\cline { 2 - 4 } & 10月17日 & 2,579 & 8.00 \\
\hline 1999 & 7月27日 & 2,023 & 6.31 \\
\cline { 2 - 4 } & 9月15日 & 1,078 & 4.74 \\
\cline { 2 - 4 } & 9月24日 & 1,381 & 5.30 \\
\hline 2001 & 10月16日 & 1,593 & 4.84 \\
\hline 2003 & 5月31日 & $1,910^{*}$ & 5.53 \\
\hline
\end{tabular}

* 2003年の流量は暫定值

図ー 2 に示した.この期間の平均年最大流量は 1,900 $\mathrm{m}^{3} / \mathrm{s}$ である. 次に, 最近の 1993 年以降について $1,000 \mathrm{~m}^{3} / \mathrm{s}$ 以上の流量が流れた出水の流量と熊田地点の水位を整理 したものを表ー 1 に示している. 1998年10月以降, $2,000 \mathrm{~m}^{3} / \mathrm{s}$ 大きく上まわるような出水は生じていない.

\section{4. 航空写真による経年変化}

\section{（1）砂州域の変化}

水際線の形状の経年変化を, 調査地点付近を撮影した 航空写真を基に調查した. 使用した航空写真は, 1967年 9月〜2003年7月の期間の 12 枚（モノクロ 4 枚，カラー8 枚）である. 図一 3 に水際線の形状を示している. 厳密 には撮影時ごとに水位が異なると考えられるため，水際 線の形状も変わると思われるが，概略の地形の変化の傾 向を知ることができる.

右岸側には大きな砂州が発達して低水路は左岸に寄り, 湾曲部では砂州の消長によって低水路流路が経年的に大 きく変動している.

右岸砂州の上流端は，1976〜1987年の期間に $12.1 \mathrm{~km}$ 地 点まで後退していたが，1996年以降は前進と後退を繰り 返した後, 2000年以降は前進した状態で安定している.

1975年における11.8〜11.4km区間の右岸砂州の減少は, すでに1967年に開始されていた低水路拡大のための掘削 に伴うものである. 1987年には砂州は再び低水路側へ拡 大しており, 1996年以降, ほぼ掘削以前の状態に戻って いる.

11.6〜11.3km区間の左岸側は，1982年まで低水路が形 成されていたが，1987年には低水路が河道中央部に移動 したことに伴って旧低水路が閉塞して砂州が形成されて いる. その後, この左岸砂州も徐々に拡大し固定化しつ つある.

\section{（2）右岸砂碟堆前緑線位置の変化}

右岸砂州上に形成された新たな砂礫堆の前縁線は, 1987年までは明確ではなかった。しかし，1996年2月で 

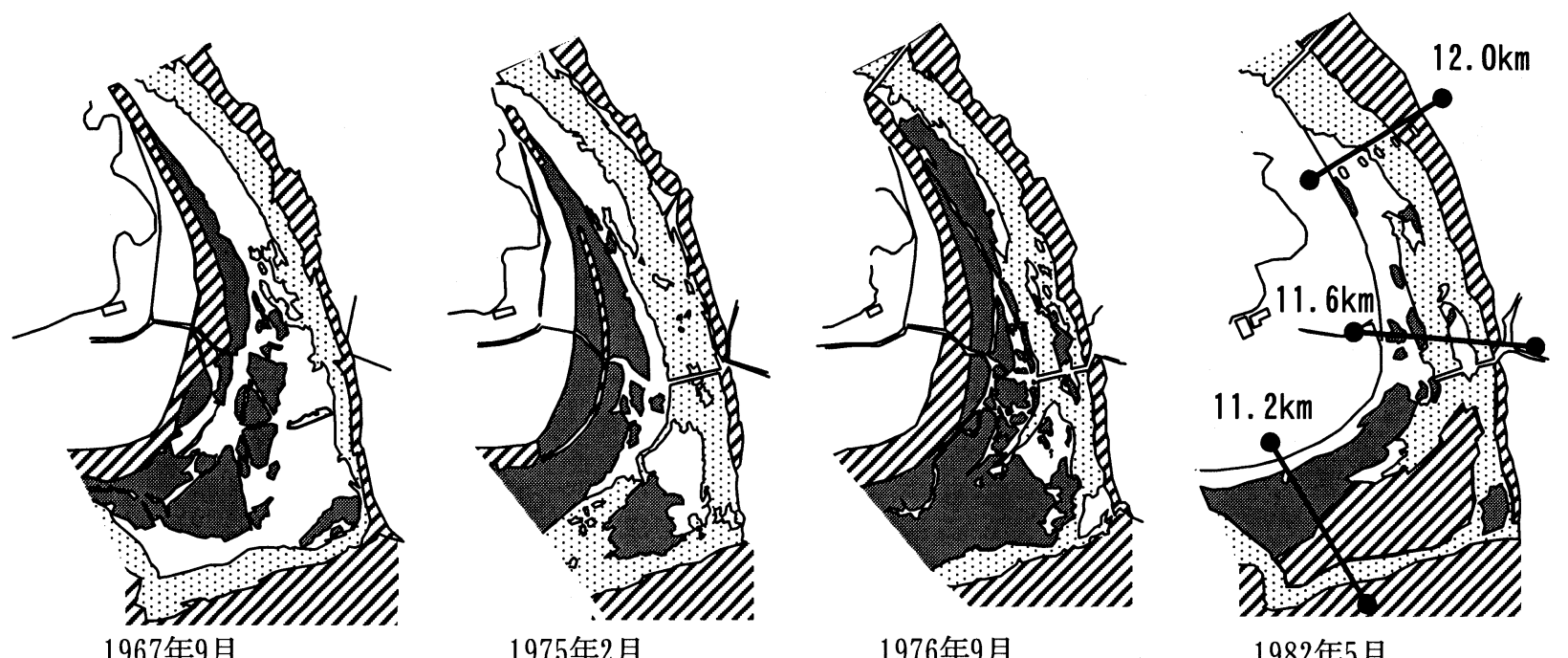

1975年2月

1976年9月

1982年5月
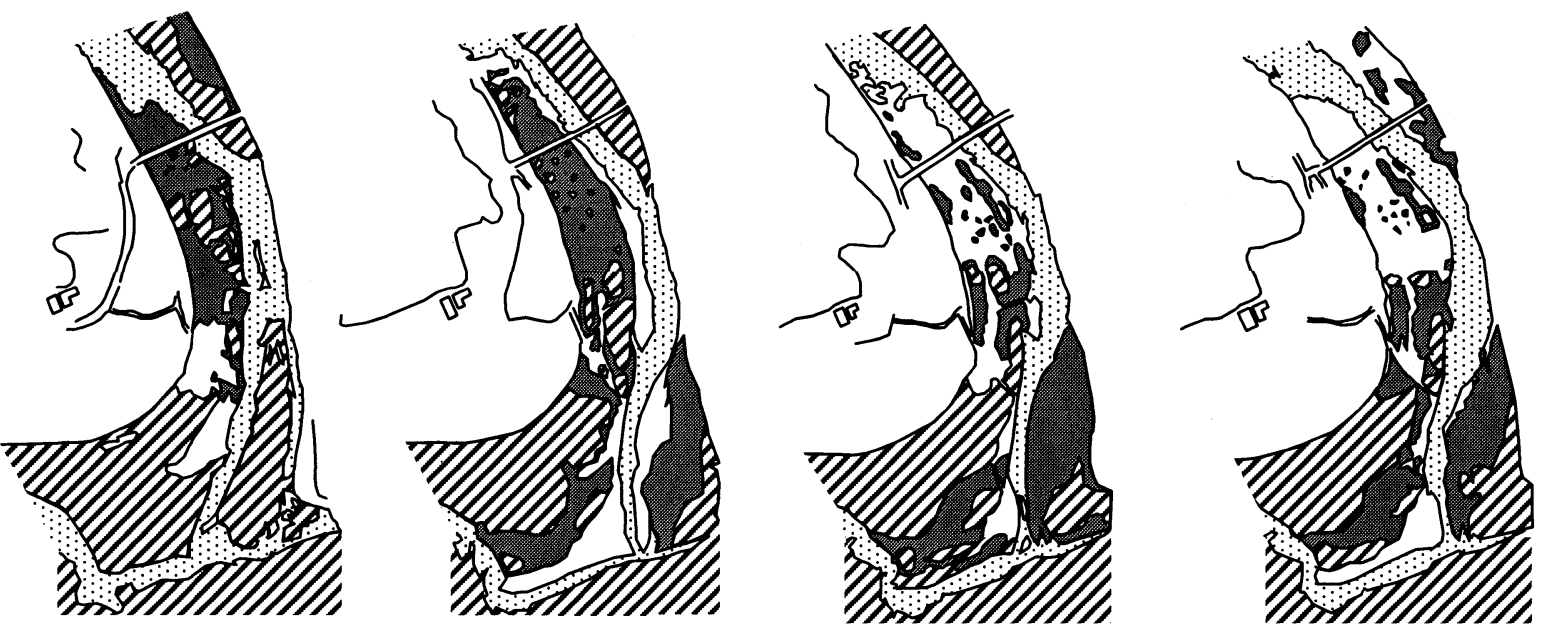

1998年4月

1999年3月
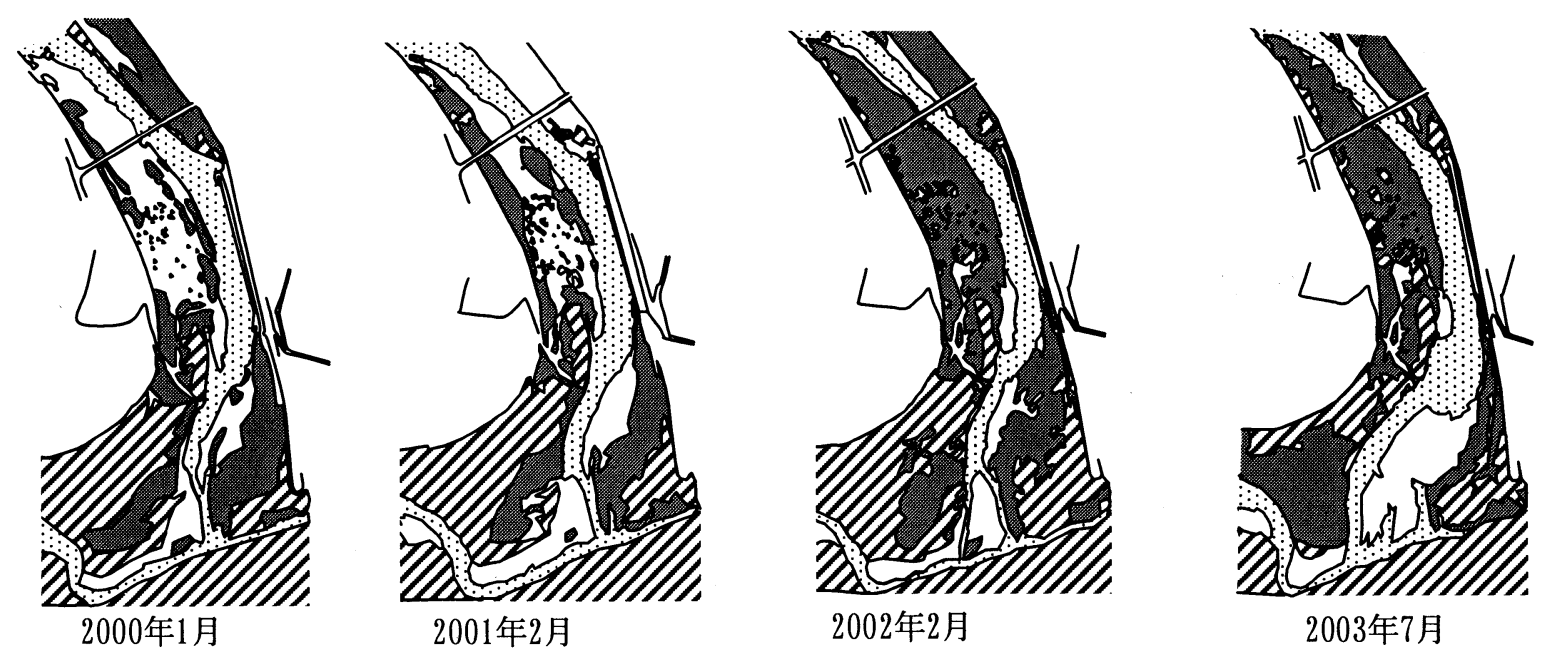

図-3 砂州上の植生域の変化

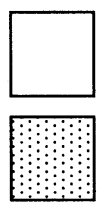

裸地

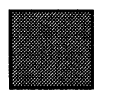

草本類

水面 曹本類 


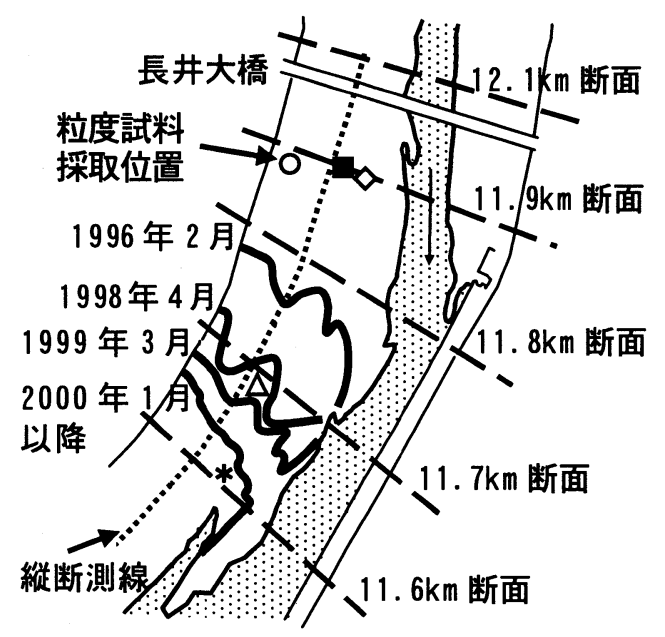

図-4 前緑線の位置

11.8km断面のすぐ下流に明瞭に形成されているのが確認 された. その後の前縁線の位置を図一4に示している. 2000年1月までは, 出水のたびに前縁線が前進したが, それ以降は前進していない。この理由には，最近大きな 出水を受けていないことや砂礫堆下流部の湾曲部樹林帯 の影響を受けていることなどが考えられる.

\section{（3）植生域の変化}

次に, 河道内の植生域の変化を調査した. 航空写真か らは, 植生群落の種の判別は難しいため, 草本類と木本 類の 2 種類に判別した.

河道内の判別結果を図ー3に併せて示している.これ によると, $11.6 \mathrm{~km}$ 地点を境に, 下流部は恒常的に植生で 覆われているが，上流部では1967年や1975年，1982年， 1998〜2001年には砂州の多くが裸地になっていて, 1987 年や1996年, 2002〜2003年には植生が回復していた.こ のうち，1982年の裸地の一部は，12km地点の橋脚建設や 1974年から開始された右岸築堤なごの建設工事に伴うも のが含まれている. しかし，これを除いても，この砂州 においては, $11.6 \mathrm{~km}$ 地点より上流で植生破壊と植生回復 が頻繁に繰り返されていることが分かる.

\section{5. 現地調査の結果}

\section{（1）砂州標高の変化}

図一 5 は, 横断測量の結果より, $11.8 \mathrm{~km}$ 地点の横断形 状を，断面内の植生分布域と併せて示したものである. 1996年11月と1997年11月の断面形状を比較すると，右岸 表小段肩から40〜 70mの位置の砂州標高が約 $1.5 \mathrm{~m}$ 上昇 しており，多量の砂磁が堆積したことが分かる. 図一4 の前縁線の前進からも明らかなように，1997年9月の大 出水による砂礫堆の発達を示すものである.

この断面には, 右岸堤防側と水際部にツルヨシ群落が 分布していて, その部分の地表は完全に被覆されている. 一方, 砂州中央部は, イタドリが部分的に覆っていて ジャヤナギも点在するが，砂礫が露出している．砂州標 高は, ツルヨシ群落の分布域では1997年以降にほぼ固定

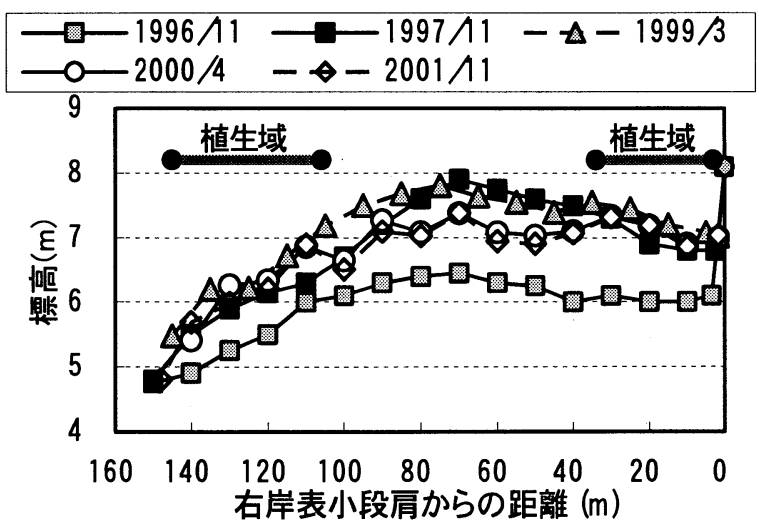

図-5 $11.8 \mathrm{~km}$ 地点の横断形状の変化

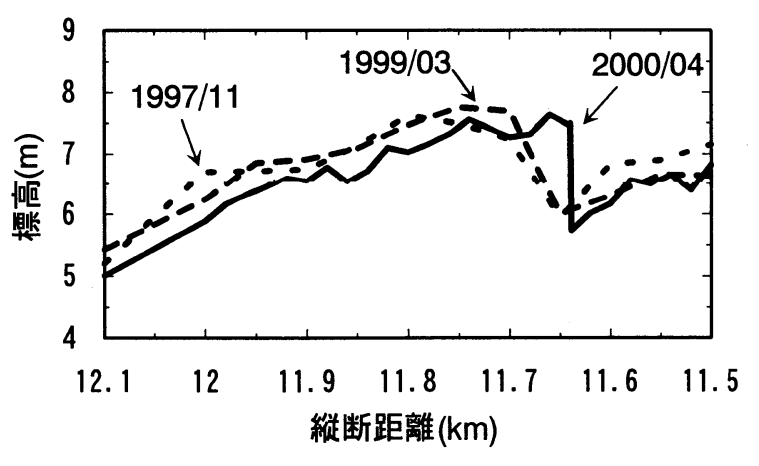

図-6 本村砂州の縦断形状の変化

あるいは上昇しているのに対して，砂州中央部では1999 年3月〜2000年4月の期間に約 $0.5 \mathrm{~m}$ 程度低下している.

図一 6 は, 右岸表小段肩から50mの位置における砂州 標高の縦断図を示したもので, 1997年と1999年は縦断方 向に50mピッチで, 2000年は10mピッチで測量した結果で ある7). 砂砂堆背面標高は1997年9月の洪水後と1999年3 月の間に大差がないが，クレスト付近での堆砂と砂磁堆 前面の前進がみられる．2000年4月には背面標高が約 $40 \mathrm{~cm}$ 低下しており, クレストも $11.64 \mathrm{~km}$ まで前進してい る. 砂州上に形成された砂礫堆は1997年以降も小出水に よって背面の砂礫が流送されて徐々に前進し, 図一 4 の ような前縁線の移動を示したことが分かる.

\section{（2）粒度特性}

\section{a) 平面分布}

前項に示したように, 砂州上のツルヨシ群落の分布域 と裸地で砂礫の移動形態が異なるので, $11.9 \mathrm{~km}$ 地点と 11. $7 \mathrm{~km}$ 地点付近で5種類の植被状態の地点を選定して粒 度分布を調査した.

試料の採取は1999年11月に行った. その粒度分布を図 - 7 に，それぞれの採取地点を図ー4に示している.

$11.9 \mathrm{~km}$ 地点の砂州中央部の裸地と植被率の低い植被地 (以下, 半裸地という)では両地点とも粒径の大きい砂礫 が多い. 右岸寄りのツルヨシ群落が分布する植被地では, 中央粒径で裸地の $1 / 4$ 程度の小さい粒径になっている. $11.7 \mathrm{~km}$ 地点直下流の砂碟堆のクレスト部の裸地では, 


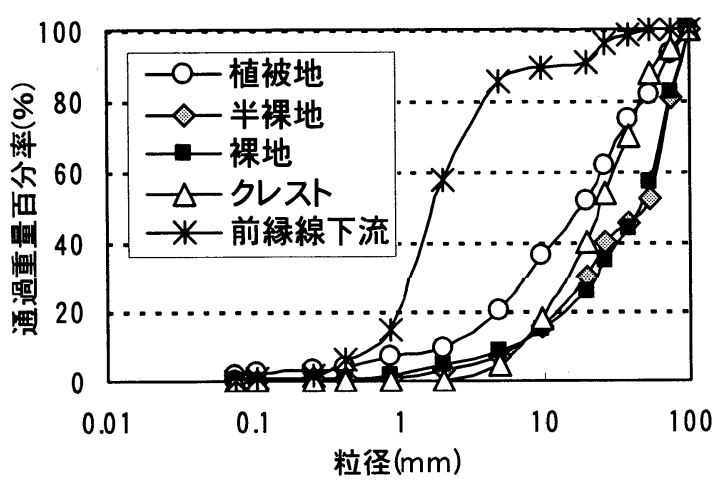

図－７砂州上の粒度分布（1999年11月）

$11.9 \mathrm{~km}$ 地点の裸地と植被地の中間の粒径であるが, $11.6 \mathrm{~km}$ 地点の前緑線下流部の植被地では, これら 4 地点 と粒径が全く異なり，10mm以下の細粒土が多い.この図 から, 裸地と半裸地では粗粒化が起こり, 植被地では細 粒化する傾向にあることが分かる. また, 砂礫堆前縁線 の下流部では細粒土が捕捉されており, その上を砂礫堆 が前進して磁層を形成していくことになる.

\section{b) 鉛直分布}

砂州には過去の出水で移動した砂碟が層状に堆積して いるものと思われる. この堆積状況を確認するために, 砂州の11.9〜11.6km区間の 5 断面において，2002年3月 28日に宮崎県延岡土木事務所に掘削を依頼して砂礫層内 の砂礫を採取し，砂礫の粒径を測定した.

測定した砂礫のうち，11.7km地点の粒度分布を図ー8

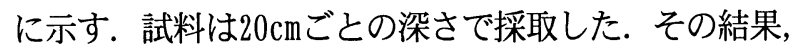
表層だけが粗粒化して粒径が大きく, 深さ約 $1 \mathrm{~m}$ と約 $2 \mathrm{~m}$ 位置に粘土混じりの細砂が分布していて，それぞれの上 下に中央粒径が30〜 40mmのほぼ同じ粒径の砂礫が堆積し ていた.

深さ約 $1 \mathrm{~m}$ と約 $2 \mathrm{~m}$ 位置の粘性土については, 11.8〜 11. 4km区間の砂州が1975〜1982年の期間には右岸側に後 退していたことや，掘削箇所の当時の河床標高は， 1974年の横断面図から $5 \mathrm{~m}$ であったこと，さらに $11.8 \mathrm{~km}$ 地点で1996年と2001年の標高の差が約1mであることを 考慮すると，深さ $2 \mathrm{~m}$ 位置の粘土混じり細砂が1975〜
1982年の期間に低水路に堆積した河床材料であると考え られる. また砂州は，1987年までに拡大しているが， 1982 1987年の期間の大きな出水が1982年8月の流量 $3,850 \mathrm{~m}^{3} / \mathrm{s}$ の出水しかないことから, 1982 年8月の出水で 発生したものと考える. したがって, 深さ1〜2m位置の 砂礫が1982年8月の出水で堆積したもの, 深さ $1 \mathrm{~m}$ 位置の 粘土混じり細砂がその後の1997年までの間に准積したも の, さらにその上の地表面までの砂碟が1997年9月の出 水で堆積したものであると判断される.

\section{6. 検討}

植生域の変化について，1997年からモニタリングを 行っているので, まず, この時期の現象を検証する. $11.7 \mathrm{~km}$ 地点よりも上流においては，1999年3月に裸地が 最も拡大していたが，2002年2月には草本類を中心とし た植生で全域が覆われている.この期間においては, 1999年7月に流量 $2,023 \mathrm{~m}^{3} / \mathrm{s}$ の出水が発生して砂砂が移動 した後は，2001年10月に流量 $1,593 \mathrm{~m}^{3} / \mathrm{s}$ の出水が発生し ている. したがって, 年最大流量が $1,600 \mathrm{~m}^{3} / \mathrm{s}$ 程度以下 の状態が2年半継続すると, 裸地の状態から草本類で砂 州全域を覆う状態まで植生が回復することが分かる.

この結果を基に, 北川での出水と砂州の地形変化およ ひ砂州上の植生域の変化との関係について考察する.

砂州の地形変化については, 11.8 11.4km区間の右岸 砂州域の拡大, 砂礫堆の発達・前進および11.6 11.3km 区間の左岸側の砂州形成が顕著である. 11.8〜 11.4km区 間の右岸砂州は，1967年に開始されていた低水路拡大の ために掘削されたが，1982年8月の出水で拡大した.こ の砂州域の拡大は，1982年5月に11. $5 \mathrm{~km}$ 地点より上流で 裸地の状態であったために, 多量の砂礫が移動して発生 したと考える. その一方で, 1979年10月に流量 3, 400 $\mathrm{m}^{3} / \mathrm{s}$ の出水が発生しているが, 砂州の上流端が後退した ものの $12 \mathrm{~km}$ 地点より下流で砂州域に大きな変化はない. 1976年9月に砂州の大部分がすでに草本類で覆われてお り, その後も出水の流量が $1,700 \mathrm{~m}^{3} / \mathrm{s}$ 以下であるから, 1979年には植生が成長して密生していたために出水時に 砂磁の移動が制限されたと推定される.したがって, 1979年と1982年の砂州拡大の相違は植被の違いによるも
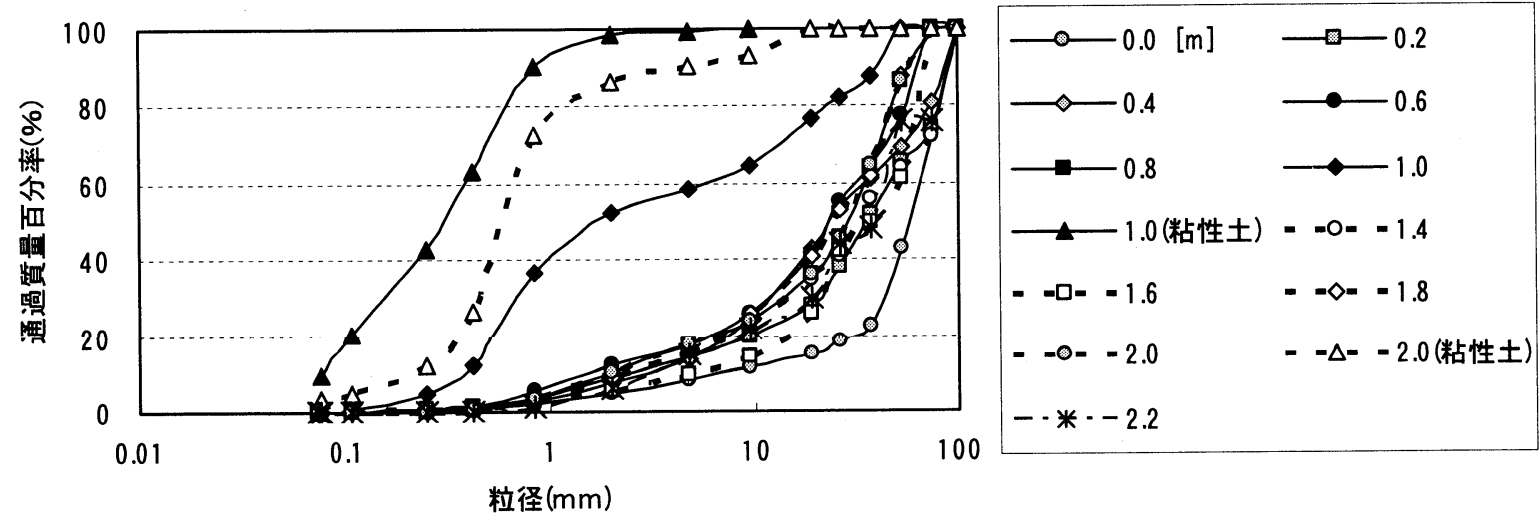

図－8 $11.7 \mathrm{~km}$ 地点の粒度分布 
のであると考える. さらに, 1997年の出水後の裸地状態 においても，図ー4，5に示したように1999年3月と 2000年4月の間に砂䃯堆が前進して砂州標高が低下して おり，砂碰が移動したことが分かる. この期間の大きな 出水は1999年7月の流量 $2,023 \mathrm{~m}^{3} / \mathrm{s}$ の出水である. 以上の 結果から, 植生が密生した状態で流量 $3,500 \mathrm{~m}^{3} / \mathrm{s}$ 級の出 水が発生しても, 砂州の規模を大きく変化させるほどの 多量の砂礫の移動は起こらないが, 裸地の部分では流量 $2,000 \mathrm{~m}^{3} / \mathrm{s}$ の出水で砂州標高を変化させる程度に砂礫が 移動するものと考えられる.

11.6〜 11. 3km区間の左岸側の堆積も1982年8月の出水 で起こったと推定される. その後も徐々に拡大していた が, 2003 年 5 月の流量 $1,910 \mathrm{~m}^{3} / \mathrm{s}$ の出水によって大きく変 化した. この湾曲部の右岸側の樹林帯は, 洪水阻害要因 となることから激特事業で低水路側が伐採の対象となつ ており，2003年1～3月に11.0～11. 2km区間が伐採された. この樹林帯が1976年と1982年の間に形成された以降は, 湾曲部右岸側の地形が安定していたのに対し，それ以前 は大きく変化している. このことは, 湾曲部右岸側の樹 林帯が，この付近の地形を安定させる効果を持っていた ことを示している. 今後の湾曲部右岸側の地形変化を注 意深く監視する必要がある.

植生域の変化については, 1999～2002年と同様の植生 回復が1983〜1987年の期間にみられる. 1982年8月の出 水で12.2 11.4km区間に多量の砂礫が堆積しているので, その直後は裸地の状態であったと推定されるが，1987年 6月には草本類と木本類が密生するまでに回復している. 1982年 9 月〜 1987 年 6 月の約 5 年間の出水を調べると, 流 量が $1,808 \mathrm{~m}^{3} / \mathrm{s}$ 以下である.このことから, 流量が 1,800 $\mathrm{m}^{3} / \mathrm{s}$ 程度以下の状態が 5 年間継続すると, 裸地の状態か ら草本類と木本類が密生する状態まで植生が回復するこ とが分かる.

1987年以後も, 1989 年まで流量が $1,600 \mathrm{~m}^{3} / \mathrm{s}$ 程度以下 の状態が継続しているので, 植生は十分に密生したと推 定されるが, 1996年2月は木本類が消失して草本類を中 心とした植生に戻っている. したがって，1989年と1996 年2月の間に大規模な植生破壊が生じたことになる.こ の期間には1990年と1993年に流量 $3,200 \sim 3,500 \mathrm{~m}^{3} / \mathrm{s}$ の出 水が発生している. したがって, 草本類と木本類が十分 に密生した状態であっても, 流量 $3,500 \mathrm{~m}^{3} / \mathrm{s}$ 級の出水が 発生すると，木本類が消失する大規模な植生破壊が発生 することが分かる．このことを踏まえると．1967年の裸 地状態はその前年の流量 $3,740 \mathrm{~m}^{3} / \mathrm{s}$ の出水で発生し, 1975年の裸地状態もその前年の流量 $3,360 \mathrm{~m}^{3} / \mathrm{s}$ の出水で 発生したものと判断される.

\section{7. まとめ}

以上のように，本村砂州を対象として，種々の現地 調査や資料調査, 聞き取り調査を行って, 北川における 出水之砂州の地形変化および砂州上の植生域の変化の関
係について検討を行った. その結果をまとめると以下の ようである.

1） $11.7 \mathrm{~km}$ 地点においては, 深さ $2 \mathrm{~m} の$ 位置に1975〜1982 年の期間に河床に堆積した粘土混じり細砂が分布し， 深さ1〜2m位置に1982年8月の出水で堆積した砂礫, 深さ $1 \mathrm{~m}$ 位置にその後の1997年までの間に堆積した粘 土混じり細砂, さらにその上の地表面までの層に 1997年9月の出水で堆積した砂礫が分布している.

2) 砂州が裸地状態であると, 流量 $2,000 \mathrm{~m}^{3} / \mathrm{s}$ の出水で砂 州標高が変化する程度に砂礫が移動する.

3）植生が密生した状態であると, 流量 $3,500 \mathrm{~m}^{3} / \mathrm{s}$ 級の出 水が発生しても砂州の規模を大きく変化させるほど の多量の砂礫の移動は起こらないが，木本類が消失 する大規模な植生破壊が発生する.

4) 湾曲部の樹林帯は, この付近の砂州地形を安定させ る効果を持っていた.

5) 年最大流量 $1,600 \mathrm{~m}^{3} / \mathrm{s}$ 程度以下の状態が 2 年半継続する と, 裸地の状態から草本類で砂州全域を覆う状態ま で植生が回復する.

6) 年最大流量 $1,800 \mathrm{~m}^{3} / \mathrm{s}$ 程度以下の状態が 5 年間継続する と, 裸地の状態から草本類と木本類が密生する状態 まで植生が回復する.

以上によって，北川において砂州の地形変化と植生域 の変化が過去どのように繰り返されてきたのかを, 定量 的に把握することができた. 今後は, 流れの解析による 理論的な裏付けを行うとともに, 激特事業によって変形 を受けた砂州のモニタリングを継続するなど，物理環境 と植生の変化について検討する予定である.

謝辞 : 本研究は, 北川における河川生態学術研究会の総 合的な調査研究の一部として実施したものである. 資料 については国土交通省国土技術政策総合研究所および延 岡河川国道事務所, 宮崎県土木部から提供していただい た. ここに記して感謝の意を表します.

\section{参考文献}

1) 砂田憲吾ら : 河川管理のための植生の調査方法, 河川整備基 金事業, 52p., (財)河川環境管理財団, 1996.

2) 九州地方建設局・宮崎県・(財)リバーフロント整備セン ター：五ヶ瀬川水系北川 北川「川づくり」検討報告書, 1999.

3) 杉尾哲, 渡邊訓甫, 田上篤志 : 植生の回復過程にある砂州で の洪水による草本植生破壊の検討, 水工学論文集, 第47巻, pp.1003-1008, 2003.

4) 池内幸司 : 北川激特事業における良好な河川環境の保全・復 元を目指した川づくり，河川と自然環境. 理工図書. pp.6772, 2000.

5) 山本晃一 : 沖積河川学 堆積環境の視点から, 山海堂, pp.35-42, 1994.

6) 久野敦史, 杉尾哲 : 北川長井地区における砂州内植生之砂州 地形変化に関する研究, 宮崎大学工学部紀要, 第30号, pp.207-212, 2001.

7) 西畠康裕, 渡邊訓甫, 杉尾哲 : 砂州と植生を有する湾曲部の 流況特性について, 土木学会第56回年次学術講演会講演概要 集, II-113, pp.226-227, 2001.

(2003.9. 30受付) 